\section{Az idő, mint a vezetői tevékenység erőforrása}

\author{
Bácsné Bába Éva \\ Debreceni Egyetem Agrár- és Müszaki Tudományok Centruma, \\ Gazdálkodástudományi és Vidékfejlesztési Kar, \\ Vezetés- és Szervezéstudományi Intézet, Debrecen \\ bbeve@freemail.hu
}

\section{ÖSSZEFOGLALÁS}

Az idötényezö egyre jelentősebb szerephez jut a gazdálkodásban. A változás a szervezet, a vezetés, a személy oldaláról irányítja rá a figyelmet. Agribusinesshez köthetö tevékenységü vállalkozások vezetőivel készitett kérdöives felmérés során vizsgáltam a vezetők időgazdálkodási gyakorlatát, és a szervezetek adaptációs képességét jellemzö reakció időt. A begyüjtött adatokat tudományosan megalapozott statisztikai módszerekkel elemeztem.

Eröforrás vizsgálatok során az időtényezöt két aspektusból elemeztem. Egyrészt arra voltam kíváncsi, hogy a megkérdezett vezetők milyen szerepet tulajdonitanak az időnek a vállalati hatékonyság, eredményesség növelésében, másrészt arra kérdeztem rá, hogy mennyire érzik bővithetőnek ezt az eröforrást.

Kulcsszavak: időtényezö, erőforrás, vezetői időgazdálkodás, vállalati hatékonyság, eredményesség

\section{SUMMARY}

The role of the time factor in management is increasing Change directs attention to the time factor from the point of view of the organisation, and management does the same from that of the person. I examined the time management practice of managers of organisations related to agribusiness, and the reaction time characterising the adaption ability of the organisations through a questionnaire survey. I analysed the collected data with scientifically established statistical methods.

During studying resources I analysed the time factor from two aspects. On the one hand, I wanted to know what role time has in managers' opinions in increasing company efficiency and performance. On the other hand, I asked them how much they consider this resource to be expandable.

Keywords: time factor, resource, managers' time management, company efficiency and performance

\section{BEVEZETÉS}

A vezetők feszített munkatempójuk miatt túlterheltek, kimerültek. Állandó időhiánnyal küszködnek, ami szorongáshoz, romló teljesítményhez, menedzserbetegségekhez vezethet. Ez annak a következménye, hogy a XX. század közepén felismerték, hogy a technika, a technológia fejlödése lassan eléri határait, így a termelékenység, az eredményesség növelését emberi oldalról kell megközelíteni. A vállalati eredményesség növekedése a vezetőkkel szembeni elvárássá vált, így a siker érdekében a vezetők erőn felüli munkára is vállalkoztak. Ugyanakkor keresik a személyes hatékonyság növelésének lehetőségeit is.
Ezzel összefüggésben került előtérbe az időparadoxon, vagyis az, hogy bár a rendelkezésünkre álló idő korlátozott, felhasználási lehetőségei korlátlanok. Egyrészt tehát az eredményes időgazdálkodás és a személyes, valamint a vállalati eredményesség összefügghet, másrészt a vezetők megszabadulhatnak az időhiány okozta szorongásaiktól, az erőn felüli munka fáradtságától. Vagyis, a hatékony vezetőnek törekednie kell úgy saját, mint a vállalat idejével hatékonyan gazdálkodni, így rejtett tartalékokat fedezhet fel, többletforráshoz juthat, mely a versenyképességet, a hatékonyságot javíthatja.

Napjainkban a vállalatok eredményességüket folyamatosan változó, sokszor instabil és nehezen kiszámítható környezeti feltételek mellett igyekeznek fenntartani, illetve fokozni. Az utóbbi évtizedekben a változások határozzák meg a szervezetek működését. Míg korábban a konjunkturális időszakok viszonylag jól prognosztizálhatóak voltak, addig ma a dinamikus fejlődés és a bizonytalanság a jellemző. Elképzelhetetlen üteművé vált a technológiai fejlődés, felgyorsult a termékfejlesztés folyamata, és lecsökkent az áruk, szolgáltatások életciklusa. A szervezetek környezetét tehát nem csupán állandó változások jellemzik, de maguknak a változásoknak az üteme is felgyorsult. A szervezeteket ma ez a turbulens és bizonytalan környezet kényszeríti rá a változásokhoz való alkalmazkodásra. Az, hogy a szervezet milyen gyorsan képes alkalmazkodni környezetéhez, nemcsak versenyképességét, de gyakran létezését is meghatározza. Így a szervezetek reakció ideje - a változásokhoz való alkalmazkodási idő - kulcsfontosságú tényezővé válhat.

Ezek a jelenségek irányították figyelmemet a vezető személyes idejének, és a szervezetek reakció idejének vizsgálatára. A mezőgazdaság és a kapcsolódó ellátó, élelmiszer-feldolgozó és élelmiszer-kereskedelmi ágazatokhoz tartozó szervezeteket választottam ki vizsgálati célcsoportnak. Egyrészt azért, mert a mezőgazdasági folyamatok természetfüggősége, a termelés szezonalítása, idényszerüsége, a folyamatok egymásra épülése miatt ebben az ágazatban kiemelt fontossága van az időtényezőnek. Másrészt azért, mert az agrárgazdaságban a rendszerváltás óta különösen nagy átalakulások zajlottak - a legjelentősebb a privatizációhoz és a kárpótláshoz kapcsolódó tulajdonosi szerkezet megváltozása volt, amivel együtt járt a vállalati méret csökkenése, a vállalati struktúra, a termékszerkezet és -volumen megváltozása, a foglalkoztatottak számának csökkenése -, melyek a szervezetek adaptációs 
képességéhez kapcsolódó reakció idő jelentőségére hívják fel a figyelmet.

Fő célom az volt, hogy irodalmi feldolgozás, elméleti megközelítés és saját vizsgálatok alapján komplex képet alakítsak ki az időről, feltárjam az időtényező vezetői munkában betöltött szerepét, illetve bebizonyítsam, hogy az idö, mint erőforrás a menedzseri- és a vállalati eredményesség, hatékonyság fokozásának szolgálatába állítható.

\section{ANYAG ÉS MÓDSZER}

\section{1. A kutatás előzményei}

Kutatási területem szervesen illeszkedik a Debreceni Egyetem Agrár- és Müszaki Tudományok Centruma, Agrárgazdasági és Vidékfejlesztési Kar, Vezetés- és Munkatudományi Tanszéke által indított kutatási programhoz (Berde, 2009), „A menedzsment funkcionális vizsgálatához". Kutatási témám a folyamat menedzsment fö területhez, azon belül az időgazdálkodás résztémakörhöz illeszkedik.

A vizsgálatok rendszere is igazodik a tanszéken alkalmazott módszerhez, ami kérdőíves interjút, vállalati adatgyüjtést jelent.

A szakirodalmi ajánlások figyelembe vételével összeállított kérdőívet először véletlenszerüen kiválasztott 50 vezetővel személyes próbainterjú során teszteltem. Az így szerzett tapasztalatok alapján véglegesítettem kérdéseimet, és esettanulmány segítségével dolgoztam ki a vizsgálatnál alkalmazott módszertani eljárásokat.

A végleges formát öltött kérdőíveket kérdezőbiztosok jutatták el a vizsgálatba vont szervezetekhez. A kérdezőbiztossal történő adatfelvételezés az egyik legmegbízhatóbb módszernek tekinthető (Babbie, 1999), amely biztosítja a releváns válaszadást és a kérdőívek megfelelö színtü kitöltöttségét.

A vizsgálatom jellege meghatározta a kérdőívek célcsoportját, azaz az egyes vállalkozások vezető beosztású alkalmazottait kértem válaszadásra.

A kérdőív három részre tagolható:

- Az első rész az „Általános adatlap”, a válaszadó munkahelyének szervezeti paramétereit tartalmazza.

- A második rész az „Interjúalany (személyes) azonosító adatait" tartalmazza.

- A harmadik, tulajdonképpen az érdemi információkat hordozó rész a „Vezetési interjú”, amely kérdéseiben megadtam 7-8 tényezőt, melyeket 1-től 5-ig terjedő skálán kellett minősíteni.

\section{2. Alkalmazott statisztikai módszerek}

A begyüjtött adatok jellegének figyelembe vételével, a vizsgálati célnak megfelelő feldolgozás érdekében többféle alkalmazott statisztikai elemző eljárást alkalmaztam. A kérdőívek értékelését leíró statisztikai elemzéssel kezdtem, majd hipotézisvizsgálatot, fökomponens elemzést, varianciaanalízist végeztem.

A válaszoló vezetők személyes jellemzői és a szervezetek paraméterei alapján létrehozott eltérő minőségi ismérv-csoportba tartozó tényezők összehasonlítására számtani átlagaikat vetettem össze. A számtani átlagok esetleges torzító hatásának kiküszöbölésére vizsgáltam a tényezők szórását, illetve az egyes ismérvváltozatok gyakoriságát is. Elvégeztem a tényezők pontértékeinek megoszlási és rangsor vizsgálatát.

Elemeztem, hogy a vizsgálatba vont szervezetek különböző szempontok - tevékenység, müködési forma, méret, átalakulás - alapján képzett csoportjai között van-e különbség az erőforrások és azok belső forrásból történő bővíthetőségének megítélésében.

Vizsgáltam, hogy a vezetők véleménye mutat-e szignifikáns különbséget nemük, koruk, legmagasabb iskolai végzettségük, beosztásuk, munkatapasztalatuk, beosztottjaik száma, és munkaidejük alapján. Az egy szemponthoz tartozó csoportok átlagait hipotézis vizsgálatnak vetettem alá.

$\mathrm{Az}$ ordinális skálán mért kérdésekre fökomponenseket alakítottam. A kialakult főkomponensekre csoportképző ismérvek alapján varianciaanalízist végeztem.

Az adathalmaz megbízhatóságát a reliability analízissel teszteltem. Az analízis egy Chronbach alpha mutatót képez, mely eldönti a megbízhatóságot. E mutató szerint az adatokat megfelelőnek tekintettem a további vizsgálatokra. Elemeztem azt is, hogy mely kérdést kellene törölni a kérdőívből, ha javítani szeretnék a megbízhatóságon. Ilyen kérdést nem találtam.

\section{3. A vizsgálati minta bemutatása}

A vizsgálatokban 625 vezetői interjút dolgoztam fel, melyeket kérdezőbiztosok segítségével gyüjtöttem be.

Hiányzó adatok esetén, az adott válaszadó, az adott vizsgálati szempont alapján kimaradt az elemzésből. A teljes mintára nézve a hiányzó adatok aránya $1,83 \%$ volt.

Valamennyi vállalkozás tevékenysége az agrobusinesshez köthetö, azon belül is kifejezetten mezőgazdasági tevékenységgel a cégek fele, további 5,4\%-uk élelmiszeriparral foglalkozik. A vizsgálati mintát döntően közepes üzemméretü, korlátolt felelősségű társasági formában működő szervezetek alkotják. E szervezetek több, mint 40\%-a élt át jelentős átalakulást az elmúlt időszakban.

A válaszadók jelentős része felsőfokú végzettséggel rendelkező férfi, aki föként közép- és alsóvezetői beosztásban dolgozik. A megkérdezettek közt szinte azonos arányban vannak a 30-as, a 40-es, és az 50-es korosztályhoz tartozók, de nem elhanyagolható a huszonévesek aránya sem. A válaszolók $60 \%$-a betartja a törvényesen elöírt 8 órás munkaidőt, de 40\%-uk ettől több időt tölt munkával. 


\section{ERŐFORRÁS VIZSGÁLAT}

Az erőforrások közé azokat az anyagi vagy immateriális javakat, szolgáltatásokat soroljuk, amelyeket a vállalkozások kibocsátásaik megvalósítása érdekében felhasználnak. A termelési folyamatban betöltött funkciójuk alapján hagyományosan a természeti erőforrásokat (föld, nyersanyagok, stb.), az emberi erőforrást, a tőkejavakat, a vállalkozói képességeket tartják számon termelési tényezőként. Ezen hagyományos erőforrások közé, a XX. században, mint új típusú erőforrás csatlakozott az információ.

$\mathrm{Az}$ idő is rendelkezik az erőforrások tulajdonságaival: felhasználásával többletértékhez, profithoz lehet jutni, miközben sajátos ráfordításként jelenik meg, értéke, ára van, szükösen áll rendelkezésre, más erőforrással helyettesíthető, kiegészíthető, bizonyos értelemben mobilizálható. Az időtényező jelentős szerepet játszik a szervezeti folyamatokban és a vezetői tevékenységben. Ezek alapján megállapítható, hogy szervezeti és vezetési szempontból az idő objektíven létező, jól definiálható, erőforrásként is értelmezhető gazdasági tényező. Hatása két irányú: egyrészt korlátot, másrészt előnyt jelenthet.

Ezek alapján az időt vizsgálataimban már erőforrásként szerepeltettem. A megkérdezett vezetőknek ez nem jelentett problémát, tudták az időt erőforrásként kezelni, értékelni. $\mathrm{Az}$ erőforrás vizsgálatokkal az volt a célom, hogy az időnek, mint erőforrásnak meghatározzam a helyét a többi erőforrás közt.

Ezekben a vizsgálatokban az időtényezőt két aspektusból elemeztem. Egyrészt arra voltam kíváncsi, hogy a megkérdezett vezetők milyen szerepet tulajdonítanak az időnek a vállalati hatékonyság, eredményesség növelésében, másrészt arra kérdeztem rá, hogy mennyire érzik bővíthetőnek ezt az erőforrást. Mivel a válaszokból a többi erőforrás minősítése is kiderül, rangsorukból további következtetések is levonhatók.

A kutatás első kérdésével arra kerestem a választ, hogy a vezetők az erőforrásokat a vállalati hatékonyság, eredményesség fokozása szempontjából rangsorolva, hol határozzák meg az időnek, mint erőforrásnak a helyét. A minősítéseket középértékekkel jelenítettem meg. Az átlagok elemzésekor a következő sorrend adódott: pénzügyi erőforrás, anyagi-müszaki erőforrás, emberi erőforrás, piac, információ, kapcsolat, idő. A válaszadó vezetők valamennyi erőforrást az időtényező elé helyezték. Ez alapján megfogalmazható, hogy a vezetők nem értékelik kellően az időtényező szerepét. Lehet egy vállalkozásnak elegendő pénzügyi, anyagi, müszaki, emberi erőforrása, rendelkezhet piaci kapcsolatokkal, információval az állandóan változó gazdasági környezetéről, de ha ezekre a változásokra nem időben reagál, feleslegesen birtokolta erőforrásait, azokat nem tudja eredményesen felhasználni. Ez rávilágít arra, hogy szükséges az időtényező jellemzőinek feltárása, a vezetők szembesítése a kutatási eredményekkel.

Az interjúalanyok közül bár a nők és a férfiak azonosan ítélték meg az időt, mint erőforrást, a kérdés átlagának vizsgálata mutatja, hogy a női vezetők némileg többre értékelik az időtényezőt, mint a férfiak. (Férfiak: rangok átlaga: 3,7436; Nök: rangok átlaga: 3,8258.) Szignifikáns különbség mutatkozott ebben a kérdésben a kor, a munkában töltött idő és a vállalatok üzemmérete alapján. Míg az összes többi erőforrást azonosan értékelték a különböző korú vezetők, addig éppen az idő minősítésében nem értettek egyet. A Kruskal-Wallis Test szerint a 20-29 évesek értékelik a leginkább az időt, mint erőforrást, majd a 40-49 évesek következnek, akiket az 50-59 évesek követnek, a 30-39 évesek után a sort a 60 év felettiek zárják.

Megállapíthatjuk, hogy minél fiatalabb egy vezető, annál többre tartja az időt, hisz az időgazdálkodási technikák segítségében, abban, hogy idejét képes lehet intenzívebben felhasználni. Az idősebb vezetők viszont feladataik jelentős részét már rutinszerűen oldják meg (Gulyás, 2006), már túl vannak időgazdálkodásuk racionalizálásán, az idejük hatékony kihasználása szerintük már nem fokozható, ezért tűnik számukra kevésbé fontosnak az idő.

Vizsgálataimból kiderül, minél több időt tölt valaki munkával, annál jobban értékeli az idő szerepét. Az átlagok elemzésekor azt tapasztaltam, hogy a 12 órától többet dolgozók adták a legmagasabb minősítést az időnek (a rangok átlaga: 4,2222). A 10-12 órát dolgozók minősítése a második helyre (a rangok átlaga: 4,0185), a 8-10 órát és a maximum 8 órát dolgozók minősítése pedig a harmadik helyre (a rangok átlaga: 3,72) került.

Az erőforrások és az üzemméret közti kapcsolat vizsgálatából arra következtetek, hogy minél nagyobb az üzemméret, annál fontosabb az időtényező.

a 250 fónél több foglalkoztatott estén: 3,9496,

a 10- 50 fö foglalkoztatott esetén: $\quad 3,9007$,

az 1- 9 fö foglalkoztatott esetén: 3,8511 ,

az 50-249 fö foglalkoztatott esetén: $\quad 3,6071$ volt a rangok átlaga.

$\mathrm{Az}$ erőforrás vizsgálatok második részében elemeztem, hogy a különböző erőforrásokat saját lehetőségekből mennyire tartják bővíthetőnek a kutatásba vont szervezetek vezetői.

A megkérdezettek szerint a szervezet belső forrásaiból

1.-ként az információszerzés,

2.-ként a kapcsolatok,

3.-ként az emberi erőforrások

4.-ként a piac,

5.-ként az anyagi- müszaki erőforrások,

6.-ként az idő,

7.-ként a pénzügyi erőforrások bővíthetők.

Ez mutatja, hogy a vezetök érzik, tudják, hogy az idő szűkös erőforrás, véges, korlátos, visszafordíthatatlan, fokozása csak intenzív módon lehetséges. Ebben a kérdésben a válaszadók nemre, korra, végzettségre tekintet nélkül azonosan foglaltak állást. 
A kérdőívben szereplö változókra vonatkozóan adatredukciót hajtottam végre, hogy a vizsgálatok áttekinthetőbbé váljanak. Az adatredukció során Varimax rotáció alkalmazásával adódtak a megfelelően értelmezhető fökomponens súlyok. A fökomponens súlyok megadják, hogy egy-egy főkomponens milyen mértékben befolyásolja ugyanazt a változót. Az erőforrások elemzése során adódó főkomponenseket az 1. táblázat tartalmazza.

1. táblázat

Az erőforrások jelentősége alapján képzett fökomponensek

\begin{tabular}{|l|c|c|c|}
\hline \multirow{2}{*}{ Eröforrások(1) } & \multicolumn{3}{|c|}{ Fökomponensek(2) } \\
\cline { 2 - 4 } & $\mathbf{1 . 1 a}$ & \multicolumn{1}{c|}{$\mathbf{1 . 1 b}$} & \multicolumn{1}{c|}{$\mathbf{1 . 1} \boldsymbol{c}$} \\
\hline Anyagi- müszaki erőforrás(3) & 0,835 & & \\
\hline Pénzügyi erőforrás(4) & 0,809 & & \\
\hline Kapcsolat(5) & & 0,769 & \\
\hline Piac(6) & & 0,709 & \\
\hline Idő(7) & & 0,571 & \\
\hline Emberi eröforrás(8) & & & 0,808 \\
\hline Információ(9) & & & 0,708 \\
\hline
\end{tabular}

$\mathrm{KMO}=0,739$; magyarázott varianciahányad $=67 \%(10)$

Forrás: saját vizsgálatok(11)

Table 1: Main components created by the importance of resources

Resources(1), Main components(2), Material and technical resources(3), Financial resources(4), Connections(5), Market(6), Time(7), Human Resource(8), Information(9), $\mathrm{KMO}=0.739$; explained variance proportion $=67 \%(10)$, Source: own research(11)

Ahogy a táblázat mutatja, a vizsgált mintában az erőforrások szerepe a hatékonyság, eredményesség szempontjából úgy alakul, hogy az idő a piaccal és a kapcsolatokkal viselkedik azonosan (F1. 1b.). Ezen erőforrások fontosságukat tekintve az anyagimüszaki és a pénzügyi erőforrásokat követik, az emberi erőforrást és az információt megelőzik.

Az F1.1b fökomponensbe a kapcsolatok, a piac és az idő változók kerültek be. A változók közti korrelációt azzal magyarázom, hogy ezek a tényezők mind a vállalkozás szándékától, belső adottságaitól független, ,külső környezeti tényezők”.

A faktoregyüttható mátrix mutatja, hogy a ,külső környezeti tényezők" főkomponens hatása kevésbé jelentős a vállalati hatékonyság, eredményesség tekintetében. Ez érthető, hiszen a többi erőforrás belső adottságoktól függ, a vállalkozás, saját szándékai és képességei szerint alakítható. Így az eredményességre, hatékonyságra is nagyobb lehet a befolyásoló szerepük, mint a vállalkozás által nem befolyásolható külső tényezőknek.

$\mathrm{Az}$ erőforrások belső lehetőségekből történő bővíthetősége tekintetében az idő a piaccal azonos súlyú, és valamennyi erőforrás megelőzi, ahogy a 2. táblázatból látható. Az erőforrások belső forrásból történő bővíthetöségének fökomponens vizsgálata során szinte azonos fökomponensek alakultak ki, mint az előző kérdésnél. Az egyes főkomponensekbe lévő változók összetartozása jól magyarázható.
Főkomponensek az erőforrás-bővíthetőségi vizsgálat alapján

\begin{tabular}{|l|c|c|c|}
\hline \multirow{2}{*}{ Eröforrások(1) } & \multicolumn{3}{|c|}{ Fökomponensek(2) } \\
\cline { 2 - 4 } & $\mathbf{1 . 2 a}$ & $\mathbf{1 . 2 b}$ & $\mathbf{1 . 2 c}$ \\
\hline Pénzügyi erőforrás(3) & 0,875 & & \\
\hline Anyagi- müszaki erőforrás(4) & 0,850 & & \\
\hline Információ(5) & & 0,867 & \\
\hline Kapcsolat(6) & & 0,754 & \\
\hline Emberi erőforrás(7) & & 0,512 & \\
\hline Idö(8) & & & 0,817 \\
\hline Piac(9) & & & 0,783 \\
\hline
\end{tabular}

$\mathrm{KMO}=0,730 ;$ magyarázott varianciahányad $=69,6 \%(10)$

Forrás: saját vizsgálatok(11)

Table 2: Main components created by the extensibility from own possibilities of the resources

Resources(1), Main components(2), Financial resources(3), Material and technical resources(4), Information(5), Connections(6), Human Resource(7), Time(8), Market(9), $\mathrm{KMO}=0.730$; explained variance proportion $=69.6 \%(10)$, Source: own research(11)

Az F1.2a fökomponensbe az anyagi, müszaki és a pénzügyi erőforrások kerültek. Ezt a fökomponenst „Anyagi erőforrásoknak” nevezem el. Ezek az erőforrások egyértelmüen bővíthetők a vállalkozás döntésétôl függően, bármikor, ha nem saját, hát idegen forrásból.

$\mathrm{Az}$ F1.2b fökomponens az információt, a kapcsolatot, és az emberi erőforrásokat tartalmazza. Ez a három erőforrás emberek közti kapcsolatoktól függ. A fökomponens az „Emberi kapcsolatok erőforrása" elnevezést kapta. Ahogy a név is mutatja, ezen erőforrások bővítése már nem csupán vállalati döntés kérdése, hanem a szervezetbe tartozó, vagy azon kívülálló emberek akaratától is függ.

A harmadik, F1.2c főkomponens a piacból és az időből, mint erőforrásból áll. A két erőforrás a vállalati akarattól teljesen független, külső környezeti tényező. Ahogy a faktor együttható mutatja, a megkérdezettek szerint ennek a fökomponensnek a legkisebb a szerepe az erőforrások belső lehetőségekből történő növelésében. Ez teljesen alátámasztható azzal, hogy ezek az erőforrások nem belső, hanem külső adottságok.

A fökomponensek használata megkönnyíti a további elemzéseket, hiszen kitünően alkalmazhatók a paraméteres varianciaanalízisnél, mivel normális eloszlásúak. A fókomponensek segítségével értékeltem, hogy a válaszadók csoportjai relatíve jobban, vagy kevésbé értenek egyet az adott attitüddel.

A 3. táblázat a „Külső környezeti tényezők” fökomponens (F1.1b) kor szerinti vizsgálatát szemlélteti. Az idősebb - 50 év feletti - vezetők relatíve fontosabbnak ítélték meg a kapcsolat, idő, piac hatékonyságra, eredményességre gyakorolt szerepét, a fiatalabbaknál.

A 4. táblázatban bemutatott eredmények alapján az fogalmazható meg, hogy a külső környezeti tényezők - kapcsolat, piac, idő - hatékonyság növelő szerepét teljesen ellentétesen ítélik meg az eltérő 
számú foglalkoztatottal müködő cégek vezetői. Éppen a két véglet, a mikro- és a nagy üzemméretű vállalkozások értékelik jobban ezeket a tényezőket.

3. táblázat

A „külső környezeti tényezők” főkomponens kor szerinti vizsgálata

\begin{tabular}{|l|c|}
\hline Kor(1) & $\begin{array}{c}\text { F1.1b } \\
\text { Kapcsolat(2) } \\
\text { Piac(3) } \\
\text { Idö(4) }\end{array}$ \\
\hline $20-29$ & 0,077 \\
\hline $30-39$ & 0,010 \\
\hline $40-49$ & 0,137 \\
\hline $50-59$ & $-0,103$ \\
\hline $60-$ & $-0,641$ \\
\hline szig & 0,010 \\
\hline
\end{tabular}

Forrás: saját vizsgálatok(5)

Table 3: Study of 'outer environmental factors' main component by the managers' age

Age(1), Connection(2), Market(3), Time(4), Source: own research(5)

4. táblázat

A „külső környezeti tényezők” főkomponens üzemméret szerinti vizsgálata

\begin{tabular}{|c|c|c|c|c|c|}
\hline \multirow{2}{*}{ Fökomponens(1) } & \multicolumn{3}{|c|}{ Foglalkoztatottak létszáma(2) } & \multirow{2}{*}{ Szig } \\
\cline { 2 - 5 } & $\mathbf{1 - 9}$ & $\mathbf{1 0 - 5 0}$ & $\mathbf{5 1 - 2 4 9}$ & $\mathbf{2 5 0 -}$ & \\
\hline $\begin{array}{c}\text { F1.1b } \\
\text { Kapcsolat, piac, } \\
\text { idő(3) }\end{array}$ & 0,238 & 0,056 & $-0,102$ & 0,181 & 0,022 \\
\hline
\end{tabular}

Forrás: saját vizsgálatok(4)

Table 4: Study of 'outer environmental factors' main component by size of the organisations

Main component(1), Number of employees(2), Connection, Market, Time(3), Source: own research(4)

\section{EREDMÉNYEK}

Az időtényező egyre jelentősebb szerephez jut a gazdálkodásban. A változás a szervezet, a vezetés a személy oldaláról irányítja rá a figyelmet. Agribusinesshez köthető tevékenységü vállalkozások vezetőivel készített kérdőíves felmérés során vizsgáltam a vezetők időgazdálkodási gyakorlatát, és a szervezetek adaptációs képességét jellemző reakció időt. A begyüjtött adatokat tudományosan megalapozott statisztikai módszerekkel elemeztem.

Erőforrás vizsgálatok során az időtényezőt két aspektusból elemeztem. Egyrészt arra voltam kíváncsi, hogy a megkérdezett vezetők milyen szerepet tulajdonítanak az időnek a vállalati hatékonyság, eredményesség növelésében, másrészt arra kérdeztem rá, hogy mennyire érzik bővíthetőnek ezt az erőforrást.

A vállalati hatékonyság, eredményesség szempontjából minősítve az erőforrásokat, a következő sorrend adódott: pénzügyi erőforrás, anyagi-müszaki erőforrás, emberi erőforrás, piac, információ, kapcsolat, idő. A válaszadó vezetők valamennyi erőforrást az időtényező elé helyezték. Ez alapján megfogalmazható, hogy a vezetők nem értékelik kellően az időtényező szerepét. Szembesítenünk kell öket azzal a ténnyel, hogy a mai diverzifikált, sokszor instabil és kiszámíthatatlan környezetben müködő vállalatoknak nem elegendő a megfelelö pénzügyi, anyagi, müszaki, emberi erőforrásokkal, piaci kapcsolatokkal, információval rendelkezniük, hiszen eredményességük, de akár létük is függhet attól, hogy képesek-e a változásokra időben reagálni. Ha nem, a vállalkozás feleslegesen birtokolta erőforrásait, azokat nem tudta eredményesen felhasználni. Ez rávilágít arra, hogy szükséges az időtényező jellemzőinek feltárása, a vezetők szembesítése a kutatási eredményekkel.

A vizsgált mintára jellemző, hogy minél nagyobb vállalatuk üzemmérete, a megkérdezettek annál fontosabbnak értékelik az időtényezőt. A fiatalabb vezetők is többre tartják az időt az idősebbeknél. Valószínűleg ők még hisznek az időgazdálkodási technikák segítségében, abban, hogy idejüket képesek lehetnek intenzívebben felhasználni. Az idősebb vezetők viszont feladataik jelentős részét már rutinszerüen oldják meg, már túl vannak időgazdálkodásuk racionalizálásán, az idejük hatékony kihasználása szerintük már nem fokozható.

$\mathrm{Az}$ erőforrás vizsgálatok második részében elemeztem, hogy a különböző erőforrásokat saját lehetőségekből mennyire tartják bővíthetőnek a kutatásba vont szervezetek vezetői. Ebben a kérdésben a válaszadók nemre, korra, végzettségre tekintet nélkül azonosan foglaltak állást. E szerint az idő csupán egy erőforrást előz meg. Ez úgy értelmezhetö, hogy a vezetők inkább korlátnak érzik az időt. Igaz, hogy az idő szükös erőforrás, de a többi termelési tényező esetében éppen a szükösség a gazdálkodás mozgatórugója.

A fökomponens elemzésben az erőforrások hatékonyság, eredményesség növelő szerepe úgy alakul, hogy az idő a piaccal és a kapcsolatokkal viselkedik azonosan. Ezen erőforrások fontosságukat tekintve az anyagi-müszaki és a pénzügyi erőforrásokat követik, az emberi erőforrást és az információt megelőzik. A változók közti korrelációt azzal magyarázom, hogy ezek a tényezők mind a vállalkozás szándékától, belső adottságaitól független, „külső környezeti tényezők”, és mint ilyenek, a vállalkozás által nem befolyásolhatónak tünnek. Szemben a többi erőforrással, melyek belső adottságoktól függnek, a vállalkozás saját szándékai és képességei szerint alakíthatóak, így az eredményességre, hatékonyságra is nagyobb lehet a befolyásoló szerepük.

A bővíthetőségi vizsgálatban a piac és az idő alkotott egy fökomponenst. A két erőforrás a vállalati akarattól teljesen független, külső környezeti tényező, melynek a legkisebb a szerepe az erőforrások belső lehetőségekből történő növelésében. 
$\mathrm{Az}$ idősebb - 50 év feletti - vezetök relatíve fontosabbnak ítélték meg a kapcsolat, idő, piac hatékonyságra, eredményességre gyakorolt szerepét a fiatalabbaknál.

A külső környezeti tényezők - kapcsolat, piac, idő - hatékonyság növelő szerepét teljesen ellentétesen ítélték meg a különböző üzemméretü cégek vezetői. Éppen a két véglet, a mikro- és a nagy üzemméretű vállalkozások értékelték jobban ezeket a tényezöket.

\section{IRODALOM}

Babbie E. (1999): A társadalomtudományi kutatás gyakorlata. Balassi Kiadó, Budapest

Berde Cs. (2009): A vezetés funkcionális vizsgálatának módszertani kérdései. „Jubileumi kiadvány a Miskolci Egyetem Gazdaságtudományi Kar Vezetéstudományi Intézet alapításának 50. évfordulójára”. Miskolci Egyetem, MiskolcLillafüred, 30-37.

Gulyás L. (2006): A humán erőforrás menedzsment alapjai. Szegedi Egyetemi Kiadó-JATEPress, Szeged 